\title{
Do Chinese Exports Crowd-Out African Goods? An econometric analysis by country and sector
}

\author{
Giorgia Giovannettia and Marco Sanfilippo ${ }^{\mathrm{b}}$ \\ ${ }^{a}$ Department of Economics, University of Florence and Robert Schuman Centre for Advanced \\ Studies, European University Institute, Florence \\ ${ }^{\mathrm{b}}$ Department of Economics, University of Florence
}

\begin{abstract}
To be published in European Journal of Development Research Special Issue, Vol. 24, No. 1, 2009
\end{abstract}

\begin{abstract}
Trade is a key channel through which Chinese economic growth affects the world economy and especially developing countries. Despite strong ongoing changes in its productive structure, China's comparative advantage is still in low value added manufacturing products.

African manufacturing production is confined to few traditional productions. Hence, even if at times, and in some sectors, African exports have been favoured by preferential treatments, Africa has proven to be particularly vulnerable to the competitive threat posed by China in third markets, including other African countries. With the intensification of economic relations, in fact, China has started flooding African markets with its low cost manufactures, often at the expense of local producers. Furthermore, Chinese goods are likely to crowd out cheap African manufactures in main trade partners of Africa, namely US and EU. We measure the indirect impact of China on African exports. Using disaggregated data for the period 1995-2005, we present significant evidence on the existence of a displacement effect at different levels: sector, product, region and market.
\end{abstract}

Keywords: China, Africa, Trade, Manufacturing sector, Gravity models

JEL Classification: F4, F21, F35, P45

\section{Acknowledgements}

An earlier draft version of this paper has been presented at the Second Summer School on the Chinese Economy at CERDI, University of Auvergne. We would like to thank Margherita Velucchi, Stefano Rosignoli and Aruneema Mahabir and two anonymous referees for their helpful comments. 


\section{Introduction}

The buoyant growth of China in the last twenty years, an average rate of around 10 per cent a year, has had a very positive impact on the world economy. Trade is one of the key channels (together with FDI and Aid) through which Chinese growth impacts on developing countries (Kaplinsky et al., 2006). Most countries, especially raw material producers, have benefited by this strong and increasing demand, since Chinese imports have grown at an average annual rate of $18 \%$ per cent since 1992, making China the third importer of manufacturing in 2007 (after US and Germany). However, Chinese exports have grown even more, increasing competition in destination markets, and most likely crowding out (some) non Chinese goods. Since China's competitive advantage still lays in low value added manufacturing products (Schott, 2008), despite the recent impressive changes in its productive structure and specialization, the more likely to be crowded out are low tech manufacturing productions, such as those of Africa.

Most African countries do not yet have a very developed manufacturing sector and rely on few traditional productions. While, at times and in some sectors, African exports might have been favoured by preferential treatments, Africa is therefore vulnerable to the competitive threat posed by China in third markets. With the intensification of economic relations, in fact, China has started flooding African markets with its low cost manufactures, often at the expense of local producers.

In this paper, we measure the indirect impact of China on African exports to its main trading partners, US and EU, and to other African countries. Using disaggregated data at 6-digit level of the harmonized system (HS) classification for the period 1995-2005, we present significant evidence on the existence of a displacement effect at sector, product, region and market level.

The paper proceeds as follows. Section 2 describes the main trends of trade relationships between African countries and its main trading partners. Section 3 provides the analytical framework and reviews the literature on the impact of China on Africa through the trade channel. Section 4 specifies the econometric model, while section 5 details data and methodology. The results of our estimation are reported in section 6. Our results show that Chinese exports have a significant and negative impact on African exports to main trade partners as well as inside Africa, where the demand for non sophisticated low quality goods is expected to be high. The results are robust, also at different level of disaggregation. Section 8 concludes, drawing some policy implications.

\section{Africa trade in manufactures: with whom and what}

Following a sharp increase in overall economic relations (Biggeri and Sanfilippo, 2009), in 2006 China has become the second trade partner (and the first exporter to) of Africa, after the United States. More precisely, Europe is the main trade partner of North African countries, while US of SSA countries. Intra-regional trade is relevant for SSA countries. The UNCTAD Economic Development in Africa Report shows that African exports are mainly directed to a group of traditional partners, whose import shares have experienced little changes since the sixties (UNCTAD, 2008: 24-27). The emergence of Asia as a rapidly growing market has, however, represented a source of diversification, though only in terms of destination market and not of sectoral composition of exports (Broadman, 2007).

The EU, the largest destination market for African manufactures, accounts for around 50\% of Africa exports. Intraregional trade comes second, with $27 \%$, up from $20 \%$ in the mid-nineties, while African exports to North America have been fairly constant over the last decade, ranging between 10 and $13 \%$. The situation is clearly asymmetric when we consider imports: Africa accounts for a mere $1 \%$ of total manufacturing imports of the EU. The share of EU imports from Africa on total imports in the manufacturing sector has peaked in 2001 and has decreased slightly thereafter. This 
pattern is mainly due to a decline in imports from North Africa, despite the existence of special trade provisions in the context of the Euro-Mediterranean partnership. ${ }^{1}$ SSA countries have kept their share almost constant, also thanks to preferential agreements: the Lomé Convention (1975) the Cotonou agreement (2000) and Everything but Arms (EBA) initiative (2001). Under the EBA initiative, all imports to the EU from the Least Developed Countries are duty free, with the exception of arms. One of the main consequences of these agreements is that, following the removal of the Multi-Fiber Arrangement (MFA) in the clothing and textiles sector, SSA countries did not experience a reduction in their exports to the EU. Nonetheless, trade in textiles and clothing has not improved since the entry into force of EBA (Collier and Venables, 2007).

African exports to North America have soared since 2002, as a consequence of the choice of US to diversify its oil imports away from Middle East and, with regards to the manufacturing sector, thanks to the entry into force of the AGOA (African Growth and Opportunity Act). AGOA is a preferential agreement that extend the Generalized System of Preferences (GSP) to a larger number of products ${ }^{2}$, especially in the clothing and textiles sector (Kaplinsky and Morris, 2008) and has proven to be particularly beneficial at the expiration of MFA (end of 2004). Collier and Venables (2007) for instance show that, in the apparel sector, African exports to the US, which during the nineties had similar values than those directed to EU, increased four-folds from 2000 to 2005, most likely as direct effect of the AGOA. SSA countries are the main US partners, with a high geographical concentration on both export and import. Much of the rise of African shares in America manufacturing imports took place from 2000 onwards. After a sharp decline between 2004 and 2005, exports from most of the least developed countries included in the AGOA (e.g. Lesotho, Kenya, Madagascar, Swaziland) recovered by 2006 (Kaplinsky and Morris, 2008; Collier and Venables, 2007; World Bank, 2007). The same, unfortunately, did not happen to the main African exporters (South Africa and Mauritius) that during the period 2004-2006 have reduced considerably their exports to the US (Frazer and Van Biesebroeck, 2007).

Intra-regional trade, contrary to Asia, has never represented a primary source of trade for Africa. In 2006, 8\% of total exports from Africa were directed to other African countries. This, according to UNCTAD (2008), is due to three main reasons: the first is the similarity of the exports structures which - in absence of regional production networks - inhibits bilateral exchanges; the second has to do with high transaction costs and the presence of many barriers to trade. Against this background, Broadman (2007) and UNECA (2008) argue that non-tariff barriers, such as high bureaucracy and lack of an adequate net of internal infrastructures, increase substantially the costs of internal trade. Lastly, the large number of sub-regional agreements did not prove yet to be effective. Nonetheless, as far as the share of manufacturing sector on total exports is concerned, intra-African trade seems to be more oriented towards the secondary sector. This is due to the reduced relevance of natural resources exports on the total. Interestingly, data show that African markets are more relevant for SSA countries compared to North African, whose share of imports has been stable over the last decade and that the role of other African exporters in the continent, after having peaked in 2003, has started to decline, possibly due to the entry of new exporters.

Africa's exports shares of manufacturing in EU, US and Africa shrank during the last decade, with an acceleration from 2000. This slowdown goes together with a reduced weight of the manufacturing sector in overall African export structure (UNCTAD, 2008), since the relative decline of textiles\&clothing has not been offset by growth in other sectors. Data from UNCTAD Handbook of Statistics show that Africa has kept a share of about $2 \%$ of total world exports in wood

\footnotetext{
${ }^{1}$ The EU has signed with Mediterranean countries the Euromed Association Agreements which consist of duty free access for the associated countries to the EU market for manufactured goods.

${ }^{2}$ AGOA provisions make a distinction between apparel and non apparel products. A regional quota of $1.5 \%$ of US imports remains for apparel products (Frazer and Van Biesebroeck, 2007)
} 
related manufacturing products. Africa (and especially SSA countries) also holds a relevant position in the production of iron\&steel related manufacturing products, which nonetheless have been characterized by a declining trend in market shares over the period 1995-2006. However, some countries started producing and exporting in sectors with increasing world demand. This is the case, for instance, of South Africa, where the volume of trade in industries like machinery and mechanical appliances; electrical equipment, vehicles and transport equipment has been growing substantially since $2000 .{ }^{3}$ For instance, the automotive sector accounts for $7 \%$ of South Africa GDP and, according to some authors (Barnes and Morris, 2008: 39), "..has been the most successful manufacturing sector within the South African economy". Unfortunately, this increase has not resulted in an increase in world market shares.

In most industries, the "new" fact of the last twenty years has been the "entry" of China in the export market. For some industries characterized by labour intensive production process, in a relatively short period of time, China has become the first or second exporter worldwide, gaining considerable shares in most markets, including the less developed ones. This has happened not only in the well known case of textiles and clothing industry, but also in wood products and iron and steel. With regard to machinery and equipment, China is upgrading its production and, thanks to its large involvement in global production networks, has already increased considerably its market shares in a wide number of products.

\section{Analytical framework: Competitive effects from China}

Since its massive entry in international markets, China has been characterized by its capacity of supplying low cost manufactures in labor intensive sectors (Naughton, 2007). Following its 2001 entry into WTO, China has intensified its exports in low tech manufactures, experiencing at the same time a reallocation towards relatively more sophisticated productions (Lall and Albadelejo, 2004; Amiti and Freund, 2008). Nonetheless, rather than a real shift in the nature of its comparative advantage, China is currently experiencing an increase in the number of sectors where it enjoys a comparative advantage (Qureshi and Wan, 2008). Recent work on the trade performance of China and its pattern of export specialization (Rodrik, 2006; Fontagné et al., 2008; Schott, 2008) reveals that - in spite of an impressive productive transformation and, consequently, export specialization countries specialized in high tech productions can still be considered relatively safe. Conversely, market shares of countries relying on the production of low-tech labor intensive products shrank as a consequence of China's impressive exports growth.

In what follows we refer to the analytical framework that has been developed to analyze the impact of China and India (the Asian Drivers) on developing countries ${ }^{4}$ (Jenkins and Edwards, 2004 and 2005; IDS, 2005; Kaplinsky et al., 2006; Goldstein et al., 2006). At a general level, this framework tries to assess whether the impact of China's growth on other developing countries is complementary or competitive. This is done by an assessment of the direct and the indirect impacts. Regarding the trade channel, the direct impact is easy to measure as it is a consequence of direct interaction between China and the developing countries (Jenkins and Edwards, 2005). The direct impact can arise, for instance, from an increase in Chinese demand for a country's exports ("complementary" effect) or from a increase in Chinese export to the home market of developing country that displace local producers ("competitive" effect). On the other hand, indirect effects are more difficult to measure, since they result from China's relations with third countries (Kaplinsky et al., 2006). Thus, for instance, prices of many commodities have peaked as a consequence of China's rising demand, benefiting exports of producers from developing countries

\footnotetext{
${ }^{3}$ Also some North African countries (especially Tunisia and Morocco) and - to a lesser extent -some SSA countries (Swaziland, Cote d'Ivoire, Mauritius among the others), have recorded significant exports in these sectors.

${ }^{4}$ For a general discussion on the main effects of the Asian Drivers (i.e. China and India) on developing countries, refer to the introduction of the special issue of World Development, vol. 36 (2), 2008 (Kaplinsky and Messner, 2008).
} 
("complementary"). Conversely, growing Chinese exports to third markets may have reduced developing countries market shares in the manufacturing sector ("competitive").

Concerning the competitive impact to Africa from China, which is the main object of this study, Kaplinsky and Morris (2008) have argued that it is mainly indirect in nature, the most relevant being the reduction of market shares in developed countries and the decrease in global prices of manufactures. ${ }^{5}$

Data from UNCTAD (2008) show that China has increased its share of manufacturing exports from $3 \%$ in 1995 up to $11 \%$ in 2006 . In the same period, Africa experienced a mere $0.1 \%$ increase. Structural factors such as the lack of sea access, poor infrastructures and huge costs of doing business as well as the inability to take advantage of economies of scale are often considered among the main constraints on the development of the manufacturing sector in Africa (Carey et al., 2007). In addition, African countries have not been able to reap the benefits of international division of labor through the integration into global production networks as China did and to upgrade in more advanced productions, including in commodity based sectors (Lall, 2005; Broadman, 2007).

China's main source of competitive advantage has been historically represented by the low level of wages (Shafaeddin, 2002). Nonetheless, the level of Chinese wages is no longer that low in relative terms, especially compared to other developing countries. A recent study of the World Bank on the textiles and clothing sector does not include lower wages in the list of the competitive advantages that China holds compared to AGOA members (World Bank, 2007). Eifert et al. (2005), for instance, previously found that garment firms in Madagascar, Kenya, Ghana, Mozambique and Lesotho produce at unit labor costs lower up to $60 \%$ of those of Chinese firms from exportprocessing zones. On the other hand, productivity has been identified as the main driver of China's competitive advantage over SSA countries, together with an overall advantage in indirect costs (such as electricity, freight, water and telecommunications) of production (World Bank, 2007). Concerning the incidence of indirect costs in manufacturing exports, Eifert et al. (2005), for instance, report that they account for more than $20 \%$ of total costs in some African countries, while they represent less of $10 \%$ of trade costs in China.

Finally, Subramanian and Matthjis (2007) provide further evidence showing that, compared to China, many African manufacturing exporters lag substantially behind with respect to prices; speed to market; labor productivity and the quality of products.

Kaplinsky (2005) finds that China has strongly contributed to lower prices of manufacturing, producing what has been called a 'commodification' of manufacturing products which in turn following what has historically happened to natural resource exporters - is likely to introduce a downward pressure on terms of trade of manufacturing exporters. Kaplinsky and Santos-Paulino (2006) calculate that prices of manufactures fell mainly when the group of low per capita income countries (and especially China) were exporting more, regardless of the technological level of exports. Kaplinsky and Morris (2008), performing a detailed analysis of the unit values of US imports from SSA and China in the clothing sector (using data at 10- digit HS classification) show that SSA countries' unit values have decreased of less than $5 \%$ in 2005 while Chinese ones have reduced of almost $50 \%$.

\footnotetext{
${ }^{5}$ Kaplinsky and Messner (2008) report a less intuitive, but very significant example of indirect effects arising from China's growth. They quote the case of Lesotho, whose manufacturing exports suffered from the Rand appreciation (to which Lesotho's currency is tied), which, in turn, has been an indirect consequence of China's growing demand for South Africa's commodities. In general, however, the episode of the appreciation of the Rand has not been followed by other currencies. The IMF (2008) has recently highlighted that the ongoing boom in the prices of main commodities exported by African countries has not been followed by a strong appreciation of the real exchange rate, reducing any concern of Dutch disease.
} 
Table 1 compares the unit values of Chinese and African exports for manufacturing industries according to the ISIC rev. 2 classification for $2004 .{ }^{6}$ Using the mean of the distribution of the unit values for each industry it is possible to see that Chinese exports are more competitive than African. A similar result holds if we look at the median of the distribution.

\begin{tabular}{|c|c|c|c|c|c|c|c|c|c|c|c|}
\hline & & $\begin{array}{c}\text { Manufactu } \\
\text { ring }\end{array}$ & \begin{tabular}{|c|} 
Food, \\
beverages \\
and \\
tobacco \\
\end{tabular} & \begin{tabular}{|c|} 
Textiles, \\
wearing, \\
apparel and \\
leather
\end{tabular} & $\begin{array}{c}\text { Wood and } \\
\text { wood } \\
\text { products }\end{array}$ & $\begin{array}{c}\text { Paper and } \\
\text { paper } \\
\text { products }\end{array}$ & Chemicals & \begin{tabular}{|c|} 
Non- \\
metallic \\
mineral \\
products
\end{tabular} & $\begin{array}{c}\text { Basic } \\
\text { metals }\end{array}$ & $\begin{array}{l}\text { Machinery } \\
\text { and } \\
\text { equipment }\end{array}$ & $\begin{array}{c}\text { Other } \\
\text { manufact } \\
\text { uring }\end{array}$ \\
\hline \multirow{2}{*}{ Mean } & \begin{tabular}{|l|} 
Africa \\
\end{tabular} & 316.38 & 4.49 & 22.60 & 8.51 & 143.02 & 282.30 & 14.80 & 637.97 & 574.77 & 643.38 \\
\hline & China & 138.61 & 4.35 & 29.30 & 7.50 & 57.16 & 168.98 & 17.92 & 387.83 & 201.41 & 83.14 \\
\hline \multirow{2}{*}{ Median } & Africa & 11.35 & 2.12 & 12.93 & 2.74 & 3.86 & 6.28 & \begin{tabular}{l|l}
4.70 \\
\end{tabular} & 4.41 & 43.58 & 21.90 \\
\hline & China & 8.48 & 1.44 & 12.24 & 0.69 & 2.08 & 3.07 & 3.44 & 2.24 & 22.35 & 15.36 \\
\hline
\end{tabular}

Source: Authors' elaboration on data from BACI-CEPII dataset

This argument has to do with the so-called 'fallacy of composition' hypothesis ${ }^{7}$. Razmi (2007) has revisited this argument and shown that developing countries tend to crowd-out each others in all manufacturing sectors, including those not usually involved in such kind of competition. His empirical estimations also show that there is a strong and significant 'China effect', especially in recent years (1994-2004). As a matter of facts, in Africa's four major manufactures exports (semimanufacturing including diamonds; chemicals excluding pharmaceutical; clothing; iron and steel) Chinese exports in the period 2000-2005 have grown twice as much as the world average (Finger, 2008). In addition, for a group of countries exporting manufacturing (especially textiles and garments) under preferential treatments (MFA until 2005 and AGOA now), China is representing a more severe threat at the time when the measures expire. Evidence from the clothing sector suggests for instance that the volume of Chinese exports to US and Europe has grown at very high rates immediately after the end of MFA (Morris, 2006). Recent data show that both for North African (exporting more to the EU) and SSA countries (exporting to the US) the negative impact of the MFA removal has been higher than the successive (2006) recovery. As argued by Morris, current growth of exports from one country (China) "..will likely to be at the cost of other clothing producers in the developing world. In short, we are witnessing a zero-sum game" (Morris, 2006: $47)^{8}$. A strong competition from China has also been felt by many SSA in their domestic markets. Egziabher's (2006) analysis on a group of 98 SMEs from Ethiopia in the footwear sector reports that, due to Chinese competition, about the $60 \%$ was forced to close or to rationalize their activity. In South Africa the rapid increase in imports from China in the apparel and textiles sector contributed to a drastic decline in the formal employment. The same has happened to several other African countries (Kaplinsky, 2008).

\subsection{The impact of China on Africa through the trade channel - a brief look at the existing literature}

To our knowledge, not many studies have so far investigated the impact of China-Africa trade relations on either single countries or group of countries. The existing studies have been based on traditional measures of trade similarity, and have compared the exporting pattern of African

\footnotetext{
${ }^{6}$ In order to compare unit values of Chinese exports with Africa, we computed a weighted average, for each product at the 6-digit level of the HS classification, the weight being the value of export flows. The dataset BACI makes data on unit values at the product level available up to 2004 (Gaulier et al., 2008)

7 The fallacy of composition hypothesis is based on the view that, as many developing countries try to enter international markets, they might face insufficient demand for their goods and begin a 'race to the bottom', driving prices of exports down, (cf. Razmi, 2007; Razmi and Blecker, 2008)

${ }^{8}$ Morris (2006) compares the current situation to a previous period of export-led growth, when the newly industrialized countries (NICs) entry in international markets displaced domestic producers in the industrialized countries. These economies were not in direct competition, but rather they were involved in a positive-sum game among themselves.
} 
countries with that of China or have looked at the evolution of international market shares. Table 2 summarizes the main results.

Table 2 - Review of literature on China's impact on Africa via the trade channel

\begin{tabular}{|c|c|c|c|}
\hline Paper & Methodology & Data & Main Findings \\
\hline Shafaeddin (2002) & $\begin{array}{c}\text { Rank correlation of RCA } \\
\text { and qualitative assessment } \\
(1992-93 \text { and 1997-98) }\end{array}$ & 3-digit SITC & $\begin{array}{l}\text { Only few African countries in a few products are found to have been affected by China competition. } \\
\text { Egypt and Malawi in clothing and textiles; Tunisia in machineries\&equipment items and - to a lesser } \\
\text { extent - Kenya in plastic articles have reduced their market shares over the two benchmark periods as a } \\
\text { consequence of China's competition. }\end{array}$ \\
\hline Jenkins and Edwards (2005) & $\begin{array}{c}\text { Export Similarity Index } \\
\text { (2003) and competition in } \\
\text { world export shares (1990- } \\
\text { 2002) }\end{array}$ & 3- digit SITC & $\begin{array}{c}\text { Limited overlap in ESI (except for South Africa, Kenya, Namibia and Senegal)- Competition analysis } \\
\text { shows China being a major threat for Lesotho }(89.1 \% \text { of exports); Zambia }(82 \%) \text {; Mozambique } \\
(73.4 \%) \text {; Malawi (64\%); Namibia }(55.4 \%) \text { and South Africa }(54.4 \%)\end{array}$ \\
\hline Goldstein et al. (2006) & $\begin{array}{l}\text { Export Similarity Index } \\
\text { (2003) and RCA }\end{array}$ & 3- digit SITC & $\begin{array}{c}\text { Limited overlap in ESI (except for South Africa and Kenya) - RCA Analysis shows competition with } \\
\text { Burkina Faso, Ethiopia, Kenya and Mali (leather products); Lesotho and Malawi (clothing); Tanzania } \\
\text { (textiles) }\end{array}$ \\
\hline Stevens and Kennan (2006) & \begin{tabular}{|c|}
$\begin{array}{c}\text { Export- Import overlaps at } \\
\text { the product level (1998- } \\
\text { 2003) }\end{array}$ \\
\end{tabular} & 6-digit HS & $\begin{array}{l}\text { Trade overall balance effect for the African countries on the sample (30) is positive, except for Malawi. } \\
\text { Losses are recorded, in more than one product, for South Africa (4); Nigeria (3); Kenya (2) and Ghana } \\
\text { (2) }\end{array}$ \\
\hline Broadman (2007) & $\begin{array}{c}\text { Trade-FDI (Value Chain } \\
\text { Analysis) }\end{array}$ & 1 & $\begin{array}{l}\text { The study identifies three possible complementarieties among China-Africa trade-investment nexus: 1) } \\
\text { vertical complementarieties in the cotton-textile-garment value chain (Mauritius; Nigeria; South Africa); } \\
\text { 2) upgrade in the exports of natural resources (more processing done locally); 3) increasing intra- } \\
\text { industry trade with emerging African hubs (South Africa and Nigeria) }\end{array}$ \\
\hline Zafar (2007) & $\begin{array}{l}\text { Quantitative analysis on } \\
\text { China's impact on terms of } \\
\text { trade of SSA (2000-2005) }\end{array}$ & $\begin{array}{c}4 \text { and 2- digit } \\
\text { HS }\end{array}$ & $\begin{array}{c}\text { Countries have been classified as winner; losers and mixed according to the effect of China on their } \\
\text { terms of trade. Winners are oil-exporters and natural resources rich countries (Angola; Sudan; Gabon; } \\
\text { Zambia). Mixed are resource-rich (metals and cotton) but oil- importing countries (Bootswana; Central } \\
\text { African Rep; Mali; Burkina). Losers are oil-importers that are also textile exporters (Mauritius; } \\
\text { Madagascar) or coffee and other agricultural commodities exporters (Ethiopia; Kenya; Malawi; } \\
\text { Zimbabwe). }\end{array}$ \\
\hline Geda and Meskel (2007) & $\begin{array}{l}\text { Gravity model on the } \\
\text { displacement effect in the } \\
\text { textiles and accessories } \\
\text { sector (1995-2005) }\end{array}$ & $\begin{array}{c}\text { 3- digit SITC } \\
\text { rev. } 3\end{array}$ & $\begin{array}{l}\text { China's exports of clothing and accessories is found to have displaced African exports. Niger, Zambia } \\
\text { and Burkina are the most vulnerable countries followed by Ghana, Algeria, Gabon, Cotè d'Avoire and } \\
\text { Kenya. }\end{array}$ \\
\hline Jenkins (2008) & $\begin{array}{l}\text { Static and dynamic index } \\
\text { of competitive threat } \\
(1990-2002)\end{array}$ & 3- digit SITC & $\begin{array}{l}\text { The static index of competitive threat does not show high competition in exports (especially for Nigeria } \\
\text { and Cameroon). The dynamic index shows a rising threat for all the African countries in the sample (6), } \\
\text { especially for Mozambique, South Africa and Uganda. }\end{array}$ \\
\hline
\end{tabular}

Source: Authors' elaboration

Results do not seem to be conclusive on whether the entry of China into the world export market has been particularly detrimental for African countries. Studies based on export similarity measures and rank correlation of comparative advantage indexes find very few cases of African countries exporting in the same industries of China. However, as suggested by Jenkins (2008) traditional measures of export similarity and correlation of export structures may be misleading, since China (a big country) is compared with small countries, whose exports are often concentrated in few products. Studies also taking market shares into account seem to provide more reliable information. In this case, looking at sectors where China has increased its market shares and controlling for their importance for African exports gives probably a better picture of the magnitude of the impact of China via the trade channel. On the whole, although the export structure of many African countries is far from similar to that of China, when the impact is analyzed focussing on specific sectors (e.g. textiles) and when the dynamics of market shares and terms of trade effects are taken into account, it is possible to see that an unexpected high number of African countries has already been affected by China.

The existing studies are subject to several shortcomings. First of all, the data used are often too aggregated and, thus, they may not be able to properly account for countries whose exports are specialized at the product level. Stevens and Kennan (2006), for instance, adopt a very complex methodology (although arbitrary for some aspects of the selection process) based on data at the product level and show that the impact on African countries is quite limited. Furthermore, all these studies - with the exception of Geda and Meskel (2007) and Broadman (2007) - do not take into account the sector specificities and fail to provide an accurate analysis of the possible complementarities that might arise from increasing trade relationships with China. Finally, none of these studies includes North Africa. 
Exploiting the descriptive evidence presented, and trying to avoid the above mentioned shortcomings in the existing literature, in the following we estimate a disaggregated model to measure the impact of China on exports of African countries to its main trading partners. An empirical analysis using disaggregated data on exports at the product level can provide precise information on the products that are simultaneously exported by China and African countries. This, allows us to combine some of the basic assumptions of the different approaches reviewed. On the one side, the empirical analysis allows us to see how many products exported by African countries and China are in direct competition. On the other side, adopting a dynamic specification of the model allows us to see whether an increase of Chinese exports corresponded to a reduction of African ones on a year-to-year basis. This can be considered - to some extent - a good proxy to analyze the evolution of market shares of African countries under direct competition of China and see whether China has crowded out any African country in any sector/country.

\section{Model specification}

To estimate the effect of China on African manufactures exports, and see whether these have been crowed out in EU or US or within Africa, we need to estimate African exports. We perform this task at a very disaggregated level, using an 'augmented' gravity model. Gravity models have been widely adopted to analyze the impact of trade-related policies such as the effects of participation to free trade agreements (Fontagnè and Zignago, 2007; Geda and Kebret, 2007; Collier and Venables, 2007) or to monetary unions (Serlenga and Shin, 2004); to evaluate the impact of any policy regime that can ease trade (Broadman, 2007) and to investigate the relations existing among various forms of internationalization (Egger and Pfaffermeyr, 2005; Bezuidenhout and Naudé, 2008). More recently, gravity models have also been adopted to measure displacement effects (Palley, 2003; Blecker and Razmi, 2008), to investigate the impact of China on Asian trade performance (Eichengreen et al., 2004; Eichengreen and Tong, 2006; Greenaway et al., 2006), and the effects of China and India' textile exports on a small group of African countries (Geda and Meskel, 2007). To do this, the traditional gravity equation has been augmented including Chinese exports to the same markets among the independent variables (cf Eichengreen et al., 2004).

Nonetheless, a static specification of such a model does not allow to properly put together a country (China), whereas manufacturing accounts for $90 \%$ of GDP and with relatively high market shares in many of the products considered and African countries, with very low values of exports in comparison. Since our aim is to investigate the existence of a displacement effect in third markets, a methodology taking into account the dynamics of trade relations is more appropriate (Bun and Klaassen, 2002; Jenkins, 2008). First differencing export values gives us the opportunity to see whether an increase of a country's imports from China contribute to reduce the imports from Africa on a year-to-year basis. This information is more insightful the most disaggregated the data. Using such an approach at the product level allows us to say whether - when exporting the same product in the same year - the competition of China has resulted in low opportunities of exporting for Africa.

We use a modified version of the model that has been adopted in previous studies (Eichengreen $e t$ al., 2004; Greenaway et al., 2006; Geda and Meskel, 2007), which includes the first difference of trade flows, i.e. African exports (X) and Chinese exports (CH_EXP), and the annual GDP growth rates of both the importer and exporter instead of the levels of GDP.

We use natural logarithms, which has important consequences. Given that the difference between two $\operatorname{logs}$ can be written as the $\log$ of the ratio of two variables, variables $\mathrm{X}$ and $\mathrm{CH}$ EXP in equation (1) can be interpreted as the annual changes in the value of export from the African country $i$ to country $j$ (the same in the case of China's exports to country j). Our final model results in: 
Where $\alpha$ is the constant, $i$ represents the African exporter, $\mathrm{j}$ the third country market (importer), $\mathrm{h}$ is one of the 6-digit products and $t$ is the year, covering the 1995-2005 period. X represents the value of exports of the African country $i$ to the third market $j$ of the product $h$ at year $t$. Similarly, CH_EXP is the value of Chinese exports to the third market $j$ of the product $h$ at year $t$. GDPgrow is the annual rate of growth of GDP of, respectively, the exporter $i$ and the importer $j$. $T$ is a set of time invariant variables, measuring some of the unobservable determinants of trade among the $\mathrm{n}(\mathrm{i} \mathrm{x}$ j) couples of countries. In this case, $T$ includes measures of barriers to trade such as the bilateral distance and the remoteness of exporters (landlocked). TA includes a set of dummy variables that indicate whether the African exporter $\mathrm{i}$ is currently in a preferential trade agreement with importer $\mathrm{j}$. Finally, the disturbance term eijht includes a random error term ( $\left.\varepsilon_{\mathrm{ijht}}\right)$ and the constant countries (exporter and importer), product and time specific effects $\left(u_{i}+\theta_{j}+\mu_{h}+\gamma_{t}\right)$. Assumptions made on the nature of the disturbance term are important for the correct specification of the model (Baltagi, 2005).

\section{Data, expected results and methodology}

\subsection{Data and expected results}

Data on trade flows are from the BACI dataset of CEPII. BACI has been built following a complex procedure that use UN Comtrade data and combines official f.o.b. export flows from reporting countries with mirror c.i.f. import flows to obtain the largest number of harmonized observation for each couple (exporter and importer) of countries (Gaulier et al., 2008). This allows BACI to cover a large number of countries and, thus, to report more observations compared to other trade databases. In addition, BACI is, according to its proponents, "...one of the most complete trade databases" concerning trade data on African countries (Gaulier et al., 2008: 10). All the monetary variables are reported in constant dollar $(2000=100)$. Since trade values are reported in current prices, we used as a deflator the US consumer price index deflator (IMF) when the importers were the United States and African countries and an average deflator, using data on each EU-15 country from IMF and Eurostat, in the case of the European countries .

Table 3 - Descriptive Statistics

\begin{tabular}{lcrrrr}
\hline \multicolumn{1}{c}{ Variable } & Obs & \multicolumn{1}{c}{ Mean } & Std. Dev. & \multicolumn{1}{c}{ Min } & \multicolumn{1}{c}{ Max } \\
\hline $\ln$ X & 5183977 & 2.471744 & 2.232832 & -7.157175 & 13.98489 \\
ln CH_exp & 5183977 & 3.530381 & 3.442751 & -7.150649 & 15.12284 \\
gdpgrow_i & 4742560 & 0.0799771 & 0.3584255 & -1 & 3.679487 \\
gdpgrow_j & 4775913 & 0.0702797 & 0.3965751 & -0.313 & 3.679487 \\
landlocked & 5183977 & 0.1437337 & 0.3508195 & 0 & 1 \\
ldist_ji & 5183977 & 8.387608 & 0.6958709 & 2.082319 & 9.611005 \\
agoaUS & 5183977 & 0.0195531 & 0.1384587 & 0 & 1 \\
ebaEU & 5183977 & 0.1346736 & 0.3413747 & 0 & 1 \\
comesa & 5183977 & 0.0252463 & 0.1568722 & 0 & 1 \\
ecowas & 5183977 & 0.0316811 & 0.1751496 & 0 & 1 \\
euromedEU & 5183977 & 0.0667441 & 0.2495784 & 0 & 1 \\
\hline
\end{tabular}

Data on GDPs growth are from World Bank World Development Indicators (2006). Bilateral distances, measured as a simple distance (in $\mathrm{Km}$ ) between the two most populated cities, comes from the CEPII, as well as the dummy indicating the lack of an access to the sea. Finally, we constructed the variables on the participation to free trade agreements using official information on each agreement. We selected five main agreements. Beyond the already discussed cases of AGOA and EBA that rule the GSP, respectively, of US and EU with a large number of SSA countries, we 
include the Euromed Association Agreements between the EU and Mediterranean countries. ${ }^{9}$ In addition, we include also two intra- regional agreements: the Economic Community Of West African States (ECOWAS) and the Common Market for Eastern and Southern Africa (COMESA). All these dummies have value 1 with exporter and importer in the agreement and with the agreement into force at year $t$, and 0 otherwise.

The dataset consists of 48 African exporters, including five countries from North Africa and most of SSA countries. ${ }^{10}$ The group of importers includes the main traditional markets for African exports: US, EU-15 and the same group of African countries. The BACI dataset includes about 5,000 products, however the ones in which China and Africa effectively compete are substantially less. More specifically, we included in our dataset only those products that were exported at the same time by at least one of the African country and China to the same market.

Exports from country $\mathrm{i}$ in Africa to a third market $\mathrm{j}$ depend upon four groups of variables:

\section{$\Delta \mathrm{X}=\mathrm{f}($ GDPgrow; $\mathrm{T} ; \mathrm{TF} ; \Delta \mathrm{CH}$ EXP $)$}

We expect the annual rates of growth of GDP of exporters and importers to affect positively African exports. As in standard gravity models, an increase in a country GDP induces an increase in trade, similarly here growth in GDP is expected to contribute to an increase in year-to-year trade. Conversely, the sign of the bilateral distance and of the dummy landlocked are expected to be negative. Both these variables can be interpreted as close measures of trade related barriers. In the case of Africa it has been calculated that landlocked countries face $50 \%$ higher transport costs compared to countries with access to the sea (Broadman, 2007). To participate to an active trade agreement is expected to affect exports positively, as it should allow the country to increase, or at least keep constant, the value of exports to those markets guaranteeing preferential treatment. This is especially true for the AGOA and EBA, while in the case of intra Africa agreements the scant evidence available does not allow any a priori expectations. Significant empirical evidence confirms that AGOA has contributed to an increase in the volume of trade between Africa and the US (Frazer and Van Briesebroek, 2007), especially with regard to apparels (Collier and Venables, 2007). Conversely, the only empirical analysis we are aware of accounting for the impact of EBA was not conclusive (Collier and Venables, 2007). There are no studies, to our knowledge, examining the effects of Euromed and intra-African free trade agreements. Nonetheless, evidence shows that the share of intra-COMESA and intra-ECOWAS trade has been increasing over the last decade, with the former performing better compared to the latter (UNECA, 2008). Finally, the expected sign for Chinese exports is ambiguous. If a product exported by Africa and China is a close substitute, then we can expect a crowding out effect (a negative sign). Otherwise, we can expect a positive sign or not significant coefficient. Results, however, may vary according to the sectors and the markets accounted for.

\subsection{Methodology}

Previous work on the displacement effect has adopted a two stages least squares (2SLS) estimator based on instrumental variables (IV), given that Eichengreen et al. (2004), measuring the displacement effects of China on other Asian countries exports, suggested a potential endogeneity of China's exports due to the fact that any unobservable factor that affects a country, say the US, imports from one of the (African in this case) exporters in the sample may also have an impact on

\footnotetext{
${ }^{9}$ Currently, Algeria, Egypt, Morocco and Tunisia have signed such agreements, which have entered into force at different times.

${ }^{10}$ Due to lack of individual country statistics before 2000, the five countries belonging to the Southern African Custom Unit (SACU): South Africa, Botswana, Namibia, Lesotho, and Swaziland are considered as a unique reporter.
} 
the imports from China. In the econometric literature, this means that our variable of interest, i.e. China exports, might be correlated to the error term and that instrumental variables should be adopted to avoid biased estimations. More recent studies measuring the crowding-out effects among developing countries have also adopted instrumental variables based on two stages regressions (Eichengreen and Tong, 2006; Geda and Meskel, 2007; Greenaway et al., 2006).

Panel data estimation seemed the most appropriate for our model. Nonetheless, the presence of such a high number of observation makes standard panel data estimators quite difficult to perform and computationally expensive. Hence - given the weaknesses of alternative models and following the empirical literature on the displacement effect - we performed a pooled estimation technique based on the two stages least square instrumental variables method. Pooling the data allows us to increase the degrees of freedom and to reduce the collinearity of the regressors (Baltagi, 2005). This increases the efficiency of the estimators, allowing us to get more reliable estimates of the parameters of the model (Razmi and Blecker, 2008).

The first step consists of testing the hypothesis of endogeneity of the regressor CH_EXP. Both the Wu-Hausman and Durbin-Wu-Hausman tests cannot accept the null hypothesis of exogeneity of the variable and, thus, they confirm that an instrumental variables method via 2SLS is to be preferred to the inconsistent OLS (Greene, 1993). A second step concerns testing for the presence of heteroskedasticity. In general, heteroskedasticity does not affect the consistence of the estimator (Wooldridge, 2002). Nonetheless, the standard IV/2SLS estimator is more efficient when errors are homoskedastic and independent (Baum et al., 2007a). In presence of heteroskedasticity the generalized methods of moments (GMM) is a more efficient estimator compared to 2SLS. In order to check for the presence of heteroskedasticity, we perform a Pagan- Hall test (Baum et al., 2003) ${ }^{11}$, which reject the null of no heteroskedasticity. Hence, we decided to use a model based on the generalized method of moments (GMM). In addition, given that in this case the variance of residuals is probably concentrated in groups of observations (e.g. trade between two countries in the same products in two different periods may be strongly correlated), a GMM specification with clustered errors is preferred to a robust one. ${ }^{12}$

Instruments should be correlated with the endogenous variable and uncorrelated with the error term (Wooldridge, 2002), as well as being meaningful. We use the bilateral distance between China and the importing country $\mathrm{j}$ (Eichengreen et al., 2004): it is strongly correlated to Chinese exports and independent from other variables. ${ }^{13}$ When only one instrument is adopted, the equation is considered to be exactly identified and standard overidentification tests cannot be performed. In this case, two additional identification tests (the weak identification and the under-identification test) are performed, suggesting that the choice of bilateral distance as instrument is efficient (Baum et al., 2007a, b). ${ }^{14}$

\footnotetext{
${ }^{11}$ The Pagan-Hall test has been performed on different sub-samples casually drawn from the dataset. The results have been always similar.

${ }^{12}$ Clustering allow to the GMM estimator to produce efficient results in the presence of intra-cluster correlation. In the case of equation (1) the cluster correspond to the panel identifier, i.e. the combination of the countries couple (importerexporter) with the product being traded.

${ }^{13}$ Previous works (Greenaway et al., 2006) adopt China's GDP as an additional instrument. In this case, however, its correlation to China's exports is high but it might not be exogenous (Eichengreen et al., 2004). Hence, we run an overidentification test based on the Hansen J statistics (Baltagi, 2005). Not surprisingly, the test (whose statistic is 102.811, with a p-value of 0.000) shows that identification problems may arise when China's GDP is included in the set of instruments together with bilateral distance.

${ }^{14}$ In presence of heteroskedastic errors, the Kleibergen-Paap rk statistics (Kleibergen and Schaffer, 2007) perform a LM test and reject the null of under-identification. In the latter case, the Wald F version of Kleibergen-Paap rk statistics (Baum et al., 2007b) similarly refuse the null of weak identification.
} 


\section{Results and interpretations}

Results are presented in separate paragraphs for the main sample, including all countries and sectors, by sector and by geographic origin of importers and exporters.

\subsection{Full sample}

Table 4 reports results and main tests from the estimation of equation (1). ${ }^{15}$ For comparative purposes, also results from the basic OLS regression are reported. As in Eichengreen et al. (2004), results are different when instrumental variables are not included in the final specification.

Table 4 - Full sample estimations

\begin{tabular}{|c|c|c|}
\hline$\Delta \mathbf{X}$ & OLS & 2SLS/GMM \\
\hline \multirow[t]{2}{*}{$\Delta$ lnCh_exp } & 0.006 & -0.070 \\
\hline & $(18.88)^{* * *}$ & $(10.75)^{* * *}$ \\
\hline \multirow[t]{2}{*}{ gdpgrow_i } & 0.063 & 0.065 \\
\hline & $(26.05)^{* * *}$ & $(22.41)^{* * *}$ \\
\hline \multirow[t]{2}{*}{ gdpgrow_j } & 0.023 & 0.070 \\
\hline & $(10.24)^{* * *}$ & $(15.24)^{* * *}$ \\
\hline \multirow[t]{2}{*}{ ldist_ji } & -0.013 & -0.012 \\
\hline & $(8.50)^{* * *}$ & $(11.25)^{* * *}$ \\
\hline \multirow[t]{2}{*}{ landlocked } & -0.038 & -0.037 \\
\hline & $(13.58)^{* * *}$ & $(17.64)^{* * *}$ \\
\hline \multirow[t]{2}{*}{ agoaUS } & 0.009 & 0.032 \\
\hline & $(1.40)$ & $(6.11)^{* * *}$ \\
\hline \multirow{2}{*}{ ebaEU } & 0.027 & 0.034 \\
\hline & $(9.08)^{* * *}$ & $(14.87)^{* * *}$ \\
\hline \multirow[t]{2}{*}{ comesa } & 0.014 & 0.036 \\
\hline & $(2.13)^{* *}$ & $(6.73)^{* * *}$ \\
\hline \multirow[t]{2}{*}{ ecowas } & 0.000 & -0.012 \\
\hline & $(0.01)$ & $(2.31)^{* *}$ \\
\hline \multirow[t]{2}{*}{ euromedEU } & 0.024 & 0.041 \\
\hline & $(6.76)^{* * *}$ & $(14.56)^{* * *}$ \\
\hline \multirow[t]{2}{*}{ Constant } & -0.059 & -0.076 \\
\hline & $(4.49)^{* * *}$ & $(8.03)^{* * *}$ \\
\hline Observations & 3080909 & 3080909 \\
\hline R-squared & 0.0027 & / \\
\hline Wu-Hausman $\mathrm{F}$ test & & $30.1742(0.00000)$ \\
\hline Durbin-Wu-Hausman & & $30.17414(0.00000)$ \\
\hline Pagan-Hall & & $1497.714(0.00000)$ \\
\hline Kleibergen-Paap rk LM statistics & & $7817.965(0.00000)$ \\
\hline Kleibergen-Paap rk Wald F Statistics & & $8273.832(0.00000)$ \\
\hline
\end{tabular}

$*$ significant at $10 \% ; * *$ significant at $5 \% ; * * *$ significant at $1 \%$

Absolute values of $\mathrm{t}$ statistics and robust $\mathrm{z}$ statistics in parentheses

Looking at the data, it is possible to see that control variables have generally the expected sign. All the coefficients have small numerical values, because of the adoption of first differences. The annual growth of GDP of the exporter and the importer affects positively the annual increase of African exports. More specifically, a 1\% increase in the exporters GDP growth rate causes a $0.065 \%$ growth of annual exports, while a corresponding $1 \%$ increase in the importer GDP growth is likely to augment its imports from Africa of $0.07 \%$ on an annual base. Distance and the dummy landlocked have a negative and significant sign, suggesting that these two variables represent a structural barrier for African exporters. Comparing the two coefficients, we notice that being landlocked has a larger negative impact on export growth (-0.037 versus -0.012$)$. On average, free trade agreements contribute positively to Africa trade. This means that, other things being equal, the

\footnotetext{
${ }^{15}$ Note that all the regressions below include time fixed effects that are not reported for reasons of space.
} 
existence of a free trade agreement with the trade partner allows African countries to improve export performance. Data show that this is true especially for members of AGOA, EBA, Euromed and COMESA, whose positive coefficients are very similar. A negative and significant impact is recorded with the ECOWAS. This might mean that countries involved in the agreement are likely to have increased less trade with each other compared to other destinations. More specifically, the negative sign indicates also a failure in the effective implementation of the agreement. Finally, with regard to our variable of interest, i.e. Chinese exports, our results support the existence of a displacement effect. An annual increase of the $1 \%$ of Chinese exports corresponds to a reduction of $0.07 \%$ in African exports of the same product over the same time coverage. This result has interesting implications for African countries. Considering the high level of disaggregation of the data at the product and the geographical level, this first outcome can be explained as the general tendency for African exports to its main trading partners to be outnumbered by Chinese ones when exporting the same kind of products to the same markets.

\subsection{Disaggregation by sector}

Estimation of model (1) has also been carried out on data disaggregated by sector. Although the 6digit products data from BACI at the sectoral level can be aggregated either according to the International Standard Industrial Classification (ISIC rev. 2) or the Standard International Trade Classification (SITC rev. 2), we have used the former because it provides a more comprehensive coverage of the manufacturing sector. ${ }^{16}$ In the following, however, we shall also use more disaggregated data from SITC. Table 5 below reports the results from the estimation of (1) for the whole manufacturing sector and for each of the nine manufacturing sectors of the ISIC classification. As above, data cover the full sample of African countries for the 1995-2005 period.

Results from table 5 suggest a more comprehensive picture of how much China has displaced African countries in each individual sector. The first column shows that results for the manufacturing sector as a whole are very close to those in the previous paragraph, the only difference being a slight increase in the numerical value of the coefficient related to Chinese exports. This could be interpreted as the tendency to suffer competition in a sector whereas China enjoys a set of strong comparative advantage.

\footnotetext{
${ }^{16}$ The SITC classification of manufacturing exports excludes processed food items and tobacco products (which are included in SITC 0 and 1). In contrast, the ISIC (i.e. industry-based) classification of manufacturing includes all such commodities in ISIC 311 (food products), 313 (beverages) and 314 (tobacco products). Furthermore, the ISIC classification of manufacturing also includes non-ferrous metals (ISIC 372), which are usually excluded from the SITC.
} 
Table 5 - African exports in the manufacturing sector and its main industries (ISIC 300-400), 1995-2005

\begin{tabular}{|c|c|c|c|c|c|c|c|c|c|c|}
\hline$\Delta \ln X$ & Manufacturing & $\begin{array}{c}\text { Food, } \\
\text { Beverages } \\
\text { and Tobacco }\end{array}$ & $\begin{array}{c}\text { Textiles, } \\
\text { Wearing, } \\
\text { Apparel and } \\
\text { Leather }\end{array}$ & $\begin{array}{l}\text { Wood and } \\
\text { Wood } \\
\text { Products }\end{array}$ & $\begin{array}{l}\text { Paper and } \\
\text { Paper } \\
\text { Products }\end{array}$ & Chemicals & $\begin{array}{c}\text { Non- } \\
\text { Metallic } \\
\text { Mineral } \\
\text { Products }\end{array}$ & $\begin{array}{c}\text { Basic } \\
\text { Metals }\end{array}$ & $\begin{array}{c}\text { Machinery } \\
\text { and } \\
\text { Equipment }\end{array}$ & $\begin{array}{c}\text { Other } \\
\text { Manufacturing } \\
\text { Industries }\end{array}$ \\
\hline$\Delta$ lnCh_exp & $\begin{array}{c}-0.072 \\
(10.69)^{* * *}\end{array}$ & $\begin{array}{c}0.041 \\
(2.12)^{* *}\end{array}$ & $\begin{array}{c}-0.067 \\
(3.31)^{* * *}\end{array}$ & $\begin{array}{l}-0.031 \\
(0.51)\end{array}$ & $\begin{array}{l}-0.007 \\
(0.22)\end{array}$ & $\begin{array}{c}-0.091 \\
(6.39)^{* * *}\end{array}$ & $\begin{array}{c}-0.095 \\
(3.11)^{* * *}\end{array}$ & $\begin{array}{l}-0.051 \\
(1.78)^{*}\end{array}$ & $\begin{array}{c}-0.118 \\
(9.94) * * *\end{array}$ & $\begin{array}{c}-0.061 \\
(2.00)^{* *}\end{array}$ \\
\hline gdpgrow_i & $\begin{array}{c}0.065 \\
(22.15)^{* * *}\end{array}$ & $\begin{array}{c}0.061 \\
(4.42)^{* * *}\end{array}$ & $\begin{array}{c}0.091 \\
(11.27)^{* * *}\end{array}$ & $\begin{array}{c}0.091 \\
(3.50)^{* * *}\end{array}$ & $\begin{array}{c}0.058 \\
(4.04)^{* * *}\end{array}$ & $\begin{array}{c}0.064 \\
(10.09)^{* * *}\end{array}$ & $\begin{array}{c}0.065 \\
(4.44)^{* * *}\end{array}$ & $\begin{array}{c}0.032 \\
(2.14)^{* *}\end{array}$ & $\begin{array}{c}0.066 \\
(14.63)^{* * *}\end{array}$ & $\begin{array}{c}0.081 \\
(5.32)^{* * *}\end{array}$ \\
\hline gdpgrow_j & $\begin{array}{c}0.072 \\
(15.15)^{* * *}\end{array}$ & $\begin{array}{l}-0.024 \\
(1.70)^{*}\end{array}$ & $\begin{array}{c}0.106 \\
(7.58)^{* * *}\end{array}$ & $\begin{array}{l}0.036 \\
(0.86)\end{array}$ & $\begin{array}{c}0.050 \\
(2.22)^{* *}\end{array}$ & $\begin{array}{c}0.065 \\
(6.47)^{* * *}\end{array}$ & $\begin{array}{c}0.052 \\
(2.34)^{* *}\end{array}$ & $\begin{array}{c}0.042 \\
(1.90)^{*}\end{array}$ & $\begin{array}{c}0.105 \\
(13.17)^{* * *}\end{array}$ & $\begin{array}{c}0.109 \\
(4.93)^{* * * *}\end{array}$ \\
\hline ldist_ji & $\begin{array}{c}-0.012 \\
(11.23)^{* * *}\end{array}$ & $\begin{array}{l}-0.008 \\
(1.81)^{*}\end{array}$ & $\begin{array}{c}-0.038 \\
(11.70)^{* * *}\end{array}$ & $\begin{array}{l}-0.007 \\
(0.70)\end{array}$ & $\begin{array}{c}-0.010 \\
(2.11)^{* *}\end{array}$ & $\begin{array}{c}-0.008 \\
(3.60) * * *\end{array}$ & $\begin{array}{l}-0.007 \\
(1.24)\end{array}$ & $\begin{array}{c}-0.020 \\
(3.75)^{* * *}\end{array}$ & $\begin{array}{c}-0.009 \\
(5.30)^{* * *}\end{array}$ & $\begin{array}{l}0.002 \\
(0.35)\end{array}$ \\
\hline landlocked & $\begin{array}{c}-0.038 \\
(17.78)^{* * *}\end{array}$ & $\begin{array}{c}-0.025 \\
(3.08)^{* * *}\end{array}$ & $\begin{array}{c}-0.021 \\
(2.35)^{* *}\end{array}$ & $\begin{array}{l}0.004 \\
(0.15)\end{array}$ & $\begin{array}{c}-0.038 \\
(4.04)^{* * *}\end{array}$ & $\begin{array}{c}-0.039 \\
(8.30)^{* * *}\end{array}$ & $\begin{array}{l}-0.010 \\
(0.90)\end{array}$ & $\begin{array}{l}-0.026 \\
(1.78)^{*}\end{array}$ & $\begin{array}{c}-0.046 \\
(15.39)^{* * *}\end{array}$ & $\begin{array}{c}-0.030 \\
(2.38)^{* *}\end{array}$ \\
\hline agoaUS & $\begin{array}{c}0.032 \\
(5.93)^{* * *}\end{array}$ & $\begin{array}{l}0.003 \\
(0.12)\end{array}$ & $\begin{array}{c}0.050 \\
(2.72)^{* * *}\end{array}$ & $\begin{array}{l}-0.052 \\
(0.83)\end{array}$ & $\begin{array}{l}0.016 \\
(0.65)\end{array}$ & $\begin{array}{c}0.020 \\
(1.74)^{*}\end{array}$ & $\begin{array}{l}0.026 \\
(0.82)\end{array}$ & $\begin{array}{l}0.011 \\
(0.33)\end{array}$ & $\begin{array}{c}0.046 \\
(6.16)^{* * *}\end{array}$ & $\begin{array}{c}0.046 \\
(1.75)^{*}\end{array}$ \\
\hline ebaEU & $\begin{array}{c}0.034 \\
(14.50)^{* * *}\end{array}$ & $\begin{array}{c}0.024 \\
(3.19)^{* * * *}\end{array}$ & $\begin{array}{c}0.027 \\
(3.14)^{* * * *}\end{array}$ & $\begin{array}{l}0.042 \\
(1.51)\end{array}$ & $\begin{array}{l}0.018 \\
(1.47)\end{array}$ & $\begin{array}{c}0.034 \\
(6.82)^{* * *}\end{array}$ & $\begin{array}{c}0.022 \\
(1.84)^{*}\end{array}$ & $\begin{array}{l}0.005 \\
(0.30)\end{array}$ & $\begin{array}{c}0.036 \\
(10.71)^{* * *}\end{array}$ & $\begin{array}{l}0.013 \\
(0.98)\end{array}$ \\
\hline comesa & $\begin{array}{c}0.037 \\
(6.70)^{* * *}\end{array}$ & $\begin{array}{c}0.013 \\
(0.75)\end{array}$ & $\begin{array}{c}0.052 \\
(3.68)^{* * *}\end{array}$ & $\begin{array}{l}0.010 \\
(0.23)\end{array}$ & $\begin{array}{c}0.039 \\
(1.79)^{*}\end{array}$ & $\begin{array}{c}0.050 \\
(4.72)^{* * *}\end{array}$ & $\begin{array}{c}0.077 \\
(2.80)^{* * *}\end{array}$ & $\begin{array}{c}0.052 \\
(1.80)^{*}\end{array}$ & $\begin{array}{c}0.032 \\
(2.91)^{* * *}\end{array}$ & $\begin{array}{c}0.059 \\
(1.83)^{*}\end{array}$ \\
\hline ecowas & $\begin{array}{l}-0.010 \\
(1.90)^{*}\end{array}$ & $\begin{array}{c}0.041 \\
(2.70)^{* * *}\end{array}$ & $\begin{array}{c}-0.072 \\
(4.79) * * *\end{array}$ & $\begin{array}{l}-0.008 \\
(0.23)\end{array}$ & $\begin{array}{l}-0.032 \\
(1.47)\end{array}$ & $\begin{array}{l}-0.003 \\
(0.29)\end{array}$ & $\begin{array}{l}0.045 \\
(1.42)\end{array}$ & $\begin{array}{l}0.025 \\
(0.89)\end{array}$ & $\begin{array}{l}-0.020 \\
(1.91)^{*}\end{array}$ & $\begin{array}{l}-0.008 \\
(0.26)\end{array}$ \\
\hline euromedEU & $\begin{array}{c}0.040 \\
(14.17)^{* * *}\end{array}$ & $\begin{array}{c}0.046 \\
(3.58)^{* * *}\end{array}$ & $\begin{array}{c}0.015 \\
(1.76)^{*}\end{array}$ & $\begin{array}{c}0.093 \\
(2.88) * * *\end{array}$ & $\begin{array}{c}0.056 \\
(4.00)^{* * *}\end{array}$ & $\begin{array}{c}0.056 \\
(9.56)^{* * *}\end{array}$ & $\begin{array}{c}0.048 \\
(3.23)^{* * *}\end{array}$ & $\begin{array}{c}0.024 \\
(1.72)^{*}\end{array}$ & $\begin{array}{c}0.046 \\
(10.56)^{* * *}\end{array}$ & $\begin{array}{c}0.098 \\
(6.40)^{* * *}\end{array}$ \\
\hline Constant & $\begin{array}{c}-0.076 \\
(7.83)^{* * *}\end{array}$ & $\begin{array}{c}-0.062 \\
(1.54)\end{array}$ & $\begin{array}{l}0.035 \\
(1.17)\end{array}$ & $\begin{array}{l}-0.190 \\
(1.99)^{* *}\end{array}$ & $\begin{array}{c}-0.139 \\
(3.07)^{* * *}\end{array}$ & $\begin{array}{c}0.066 \\
(3.47)^{* * *}\end{array}$ & $\begin{array}{l}0.058 \\
(1.23)\end{array}$ & $\begin{array}{l}0.079 \\
(1.64)\end{array}$ & $\begin{array}{c}-0.086 \\
(5.81)^{* * *}\end{array}$ & $\begin{array}{l}-0.031 \\
(0.60)\end{array}$ \\
\hline Observations & 2963313 & 210969 & 304121 & 28888 & 129241 & 616778 & 108913 & 119036 & 1356693 & 88674 \\
\hline
\end{tabular}

$*$ significant at $10 \% ; * *$ significant at $5 \% ; * * *$ significant at $1 \%$

Absolute values of robust $\mathrm{z}$ statistics in parentheses 
Turning to the single industries, it is interesting to note that a negative and significant sign for the variable $\mathrm{CH}_{-} \mathrm{EXP}$ has been found in four out nine divisions. On average, the magnitude of the effect is in line with that obtained for the whole manufacturing. Nonetheless, it is possible to see that for some sectors the effect has been larger. This is the case, for instance, of machineries and equipment, where the displacement has been the strongest. This result deserves further investigation. In line with our expectations as well as with the existing literature, the displacement effect in the textiles industry is confirmed. A 1\% increase of Chinese export growth of textiles products goes together with a reduction in African exports in the same sector of the $0.067 \%$. For the rest, also chemicals (that includes also petroleum refineries, coal, rubber and plastic products) and non- metallic mineral products reports an above- average negative coefficient for Chinese exports.

With regard to the control variables, they generally have both the expected sign and (often) significant coefficients. There are, however, some results to highlight. The first has to do with the effectiveness of preferential trade agreements with respect to the different sectors. Observing coefficients from table 5, it is possible to see that the positive effect of the AGOA coefficient is larger for products included in textiles and machinery and equipment compared to the manufacturing average. Conversely, the EBA seems to be more effective for textiles sector together with food, beverages and tobacco industry and chemicals products. The Euromed agreement, on the other hand, has proven to be less effective on the textiles compared to other sectors such as wood, paper and chemicals. As regards to the African agreements, the ECOWAS maintains its negative sign except for the food, beverages and tobacco division, while the effects of COMESA have been above the manufacturing average for textiles, chemicals and non-metallic mineral products. Also barriers to trade keep performing according to our expectations. It is interesting to note however that the coefficient of distance is higher in the textiles sector, whereas probably the low unit value of exports has to be balanced by a larger scale in export volumes. Similarly, the lack of access to the sea seems to represent a stronger obstacle for exports of more complex products such as those included in the machinery and equipment or in the chemical sector.

\subsubsection{The textiles and machinery industries}

Results from table 5 show that China's rise in global markets represented a further obstacle for African exports in an unexpected number of manufacturing industries. Nonetheless, there are same less clear-cut cases. This paragraph uses more disaggregate information from the BACI dataset to extend the empirical analysis to two cases which we believe may be particularly relevant for African industrialization: the traditional and labour- intensive textiles and the relatively more capital- intensive machinery and equipment sectors. Table 6 below reports the estimations based on the major groups included in the ISIC classification of industrial activities in the textiles sector. This allows us to examine in detail the groups of products where the Chinese competition has been mostly felt by African countries.

Table 6 - African exports in the main subgroups of the textiles industry (ISIC 320-330), 1995-2005 


\begin{tabular}{|c|c|c|c|c|}
\hline$\Delta \ln X$ & Textiles & Apparel & Leather & Footwear \\
\hline$\Delta$ lnCh_exp & $\begin{array}{c}-0.073 \\
(2.25)^{* *}\end{array}$ & $\begin{array}{l}-0.047 \\
(1.64)^{*}\end{array}$ & $\begin{array}{l}0.006 \\
(0.09)\end{array}$ & $\begin{array}{c}-0.209 \\
(2.52)^{* *}\end{array}$ \\
\hline gdpgrow_i & $\begin{array}{c}0.077 \\
(6.71)^{* * *}\end{array}$ & $\begin{array}{c}0.125 \\
(9.29)^{* * *}\end{array}$ & $\begin{array}{c}0.068 \\
(2.25)^{* *}\end{array}$ & $\begin{array}{l}0.055 \\
(1.52)\end{array}$ \\
\hline gdpgrow_j & $\begin{array}{c}0.092 \\
(4.21)^{* * *}\end{array}$ & $\begin{array}{c}0.119 \\
(5.77)^{* * *}\end{array}$ & $\begin{array}{c}0.110 \\
(2.14)^{* *}\end{array}$ & $\begin{array}{c}0.156 \\
(2.94)^{* * *}\end{array}$ \\
\hline ldist_ji & $\begin{array}{c}-0.043 \\
(10.06)^{* * *}\end{array}$ & $\begin{array}{c}-0.035 \\
(5.38)^{* * *}\end{array}$ & $\begin{array}{l}-0.017 \\
(1.40)\end{array}$ & $\begin{array}{c}-0.045 \\
(3.67) * * *\end{array}$ \\
\hline landlocked & $\begin{array}{l}-0.014 \\
(1.09)\end{array}$ & $\begin{array}{l}-0.020 \\
(1.26)\end{array}$ & $\begin{array}{l}-0.063 \\
(1.92)^{*}\end{array}$ & $\begin{array}{l}-0.029 \\
(1.28)\end{array}$ \\
\hline agoaUS & $\begin{array}{c}0.045 \\
(1.83)^{*}\end{array}$ & $\begin{array}{c}0.080 \\
(2.10)^{* *}\end{array}$ & $\begin{array}{c}-0.135 \\
(2.21)^{* *}\end{array}$ & $\begin{array}{c}0.143 \\
(2.75)^{* * *}\end{array}$ \\
\hline ebaEU & $\begin{array}{c}0.021 \\
(1.74)^{*}\end{array}$ & $\begin{array}{c}0.035 \\
(2.23)^{* *}\end{array}$ & $\begin{array}{l}0.015 \\
(0.47)\end{array}$ & $\begin{array}{c}0.058 \\
(2.07)^{* *}\end{array}$ \\
\hline comesa & $\begin{array}{c}0.053 \\
(2.53)^{* *}\end{array}$ & $\begin{array}{c}0.059 \\
(2.70)^{* * *}\end{array}$ & $\begin{array}{l}-0.030 \\
(0.46)\end{array}$ & $\begin{array}{l}0.060 \\
(1.38)\end{array}$ \\
\hline ecowas & $\begin{array}{c}-0.058 \\
(2.89)^{* * *}\end{array}$ & $\begin{array}{c}-0.158 \\
(4.88)^{* * *}\end{array}$ & $\begin{array}{l}-0.051 \\
(0.72)\end{array}$ & $\begin{array}{l}-0.085 \\
(1.81)^{*}\end{array}$ \\
\hline euromedEU & $\begin{array}{l}0.017 \\
(1.62)\end{array}$ & $\begin{array}{l}-0.024 \\
(1.44)\end{array}$ & $\begin{array}{c}0.059 \\
(1.82)^{*}\end{array}$ & $\begin{array}{c}0.105 \\
(3.02)^{* * *}\end{array}$ \\
\hline Constant & $\begin{array}{c}0.072 \\
(1.84)^{*}\end{array}$ & $\begin{array}{c}0.296 \\
(5.21)^{* * *}\end{array}$ & $\begin{array}{c}-0.082 \\
(0.73)\end{array}$ & $\begin{array}{c}0.174 \\
(1.59)\end{array}$ \\
\hline Observations & 175393 & 84043 & 19166 & 25519 \\
\hline
\end{tabular}

$*$ significant at $10 \% ; * *$ significant at $5 \% ; * * *$ significant at $1 \%$

Absolute values of robust $\mathrm{z}$ statistics in parentheses

Table 6 shows that the growth of Chinese exports in manufactures of textiles, wearing apparel and footwear has corresponded to a decrease in African exports for the same products. This effect has been stronger for footwear products, since a yearly increase of $1 \%$ of Chinese exports has corresponded to a decrease of African exports of $0.21 \%$. Manufactures of textiles and apparel have reduced at similar rates when Chinese exports increased. No evidence of such a displacement is found into the manufactures of leather and leather products group. It is worth noting that in three out four sectors in the textiles industry the combined effects of AGOA and EBA is equal or even greater (as in the case of apparel) than the displacement effect caused by Chinese exports.

Table 7 - African exports in the main subgroups of the machinery industry (ISIC 380-390), 1995-2005 


\begin{tabular}{|c|c|c|c|c|c|}
\hline$\Delta \ln X$ & $\begin{array}{c}\text { Fabricated } \\
\text { metal products }\end{array}$ & $\begin{array}{c}\text { Machinery } \\
\text { except electrical }\end{array}$ & $\begin{array}{l}\text { Electrical } \\
\text { machinery } \\
\text { apparatus }\end{array}$ & $\begin{array}{l}\text { Transport } \\
\text { equipment }\end{array}$ & $\begin{array}{l}\text { Professional and } \\
\text { scientific apparatus }\end{array}$ \\
\hline \multirow[t]{2}{*}{$\Delta$ lnCh_exp } & -0.092 & -0.150 & -0.150 & -0.156 & -0.013 \\
\hline & $(4.38)^{* * *}$ & $(6.55)^{* * *}$ & $(5.86)^{* * *}$ & $(3.83)^{* * *}$ & $(0.42)$ \\
\hline \multirow[t]{2}{*}{ gdpgrow_i } & 0.067 & 0.057 & 0.068 & 0.094 & 0.069 \\
\hline & $(6.77)^{* * *}$ & $(7.54)^{* * *}$ & $(7.03)^{* * *}$ & $(5.79)^{* * *}$ & $(5.67)^{* * *}$ \\
\hline \multirow{2}{*}{ gdpgrow_j } & 0.108 & 0.125 & 0.123 & 0.101 & 0.044 \\
\hline & $(7.15)^{* * *}$ & $(8.37)^{* * *}$ & $(7.26)^{* * *}$ & $(3.83)^{* * *}$ & $(1.91)^{*}$ \\
\hline \multirow[t]{2}{*}{ ldist_ji } & -0.006 & -0.012 & -0.006 & -0.010 & -0.011 \\
\hline & $(1.84)^{*}$ & $(4.37)^{* * *}$ & $(1.66)^{*}$ & $(1.77)^{*}$ & $(2.26)^{* *}$ \\
\hline \multirow[t]{2}{*}{ landlocked } & -0.051 & -0.050 & -0.033 & -0.067 & -0.028 \\
\hline & $(6.89)^{* * *}$ & $(10.25)^{* * *}$ & $(5.20)^{* * *}$ & $(8.04)^{* * *}$ & $(2.98)^{* * *}$ \\
\hline \multirow[t]{2}{*}{ agoaUS } & 0.021 & 0.042 & 0.049 & 0.105 & 0.032 \\
\hline & (1.13) & $(3.36)^{* * *}$ & $(3.25)^{* * *}$ & $(4.24)^{* * *}$ & (1.64) \\
\hline \multirow[t]{2}{*}{ ebaEU } & 0.025 & 0.043 & 0.041 & 0.028 & 0.018 \\
\hline & $(3.15)^{* * *}$ & $(7.53)^{* * *}$ & $(5.80)^{* * *}$ & $(2.98)^{* * *}$ & $(1.74)^{*}$ \\
\hline \multirow[t]{2}{*}{ comesa } & 0.039 & 0.020 & 0.088 & 0.013 & -0.080 \\
\hline & $(2.01)^{* *}$ & $(0.92)$ & $(3.60)^{* * *}$ & $(0.45)$ & $(1.74)^{*}$ \\
\hline \multirow[t]{2}{*}{ ecowas } & -0.028 & -0.044 & -0.000 & -0.004 & -0.146 \\
\hline & $(1.57)$ & $(1.82)^{*}$ & $(0.02)$ & $(0.19)$ & $(2.12)^{* *}$ \\
\hline \multirow[t]{2}{*}{ euromedEU } & 0.051 & 0.042 & 0.071 & 0.031 & 0.016 \\
\hline & $(5.28)^{* * *}$ & $(5.72)^{* * *}$ & $(7.60)^{* * *}$ & $(1.99)^{* *}$ & $(1.32)$ \\
\hline \multirow[t]{2}{*}{ Constant } & -0.201 & 0.131 & 0.063 & 0.004 & -0.064 \\
\hline & $(6.20)^{* * *}$ & $(5.48)^{* * *}$ & $(2.05) * *$ & $(0.08)$ & (1.47) \\
\hline Observations & 254135 & 495002 & 320786 & 139349 & 147421 \\
\hline
\end{tabular}

$*$ significant at $10 \% ; * *$ significant at $5 \% ; * * *$ significant at $1 \%$

Absolute values of robust $\mathrm{z}$ statistics in parentheses

Table 7 above reports similar regressions disaggregated for the five groups included in the machinery and equipment division. Transport equipment is the one reporting the strongest value for China exports. In this case, it is worth using information included in SITC rev. 2. Looking at the data at the product level, it is possible to see that, in the machinery industry, the corresponding SITC division (SITC-72: Machinery specialized for particular industries) reports a stronger negative value for China's exports (-0.24). More specifically, the Chinese exports effect is negative and significant only in three out of eight subgroups, two of which regards the medium technology construction of machineries strictly linked to the main industrial activities in Africa (SITC-721: agricultural machineries and SITC-724: textile and leather machineries). ${ }^{17}$ With regard to transport equipment industry, we find that the group including the road vehicles (SITC-78) has the strongest negative sign (-0.19). Moreover, within the road vehicles group, the only subgroup including the medium technology category of parts and accessories of the motor vehicles (SITC-784 and further disaggregation) has a significant negative sign (-0.27).

\subsection{Geographic disaggregation}

As for geography, the most relevant question is whether the displacement effect has been distributed equally among the main trading partners of Africa or if some markets have been affected more. Table 8 shows that for a group of main importers including France, Germany, Italy and the US there is evidence of displacement effect. On the contrary, a positive and significant effect is found for the exports of African countries to other African countries. For the rest of the variables, it is relevant to highlight the non significant sign of the distance coefficient in the intra-African trade, while the dummy landlocked maintains its negative sign. ECOWAS enters the regression with a

\footnotetext{
${ }^{17}$ The coefficient for SITC-721 is -0.19 , while for SITC-724 is -0.35 (they are both significant at the $5 \%$ level). The other subgroup showing a significant (and also negative) sign is the residual of this group, SITC-728, which included all the machineries for industries not included elsewhere (the coefficient reports -0.26 and significance level is $5 \%$ ).
} 
positive and significant value. With regard to regression on the main trading partners, it is worth noticing the strong positive value of the importers' GDP growth.

Very interesting outcomes emerge when the sample of importers is reduced to the subgroup including the only SSA countries and when the regression (1) is run for the intra- SSA trade. In these cases, results are straightforward as they indicates that China's rising exports to SSA countries have corresponded to a reduction in both African exports to SSA countries and in intra- SSA trade. More precisely, whereas China has increased its share of exports to SSA, this has happened at the expenses of intra-regional trade. Chinese exports in low value added manufactures have flooded SSA markets over the last decade, and a lot of anecdotic evidence has demonstrated as benefits from lower costs for the consumers have been often outnumbered by an increase in local enterprises failures and job-losses (IDS, 2005). Controlling variables are highly significant also in these cases. Importers' GDP growth has a bigger effect on intra-SSA trade compared to that of exporters. Distance, on the other side, can be considered as a less relevant obstacle for trading with closer countries compared to the lack of a coastal access. Finally, intra-African trade agreements prove to be relevant in sustaining trade growth, including the ECOWAS whose coefficient turns now positive and significant, although less relevant compared to COMESA

Table 8 - African exports in the manufacturing sector by main markets, 1995-2005

\begin{tabular}{c|ccc|c}
$\Delta$ InX & Main partners $^{\mathbf{a}}$ & Africa & SSA & SSA-SSA \\
\hline$\Delta$ lnCh_exp & -0.057 & 0.030 & -0.074 & -0.093 \\
& $(2.17)^{* *}$ & $(1.78)^{*}$ & $(3.90)^{* * *}$ & $(4.49)^{* * *}$ \\
gdpgrow_i & 0.052 & 0.054 & 0.069 & 0.076 \\
& $(12.76)^{* * *}$ & $(4.82)^{* * *}$ & $(5.93)^{* * *}$ & $(6.01)^{* * *}$ \\
gdpgrow_j & 0.563 & 0.024 & 0.108 & 0.123 \\
& $(16.31)^{* * *}$ & $(1.89)^{*}$ & $(7.98)^{* * *}$ & $(8.32)^{* * *}$ \\
ldist_ji & -0.016 & 0.006 & -0.009 & -0.009 \\
& $(11.16)^{* * *}$ & $(1.61)$ & $(2.54)^{* *}$ & $(2.42)^{* *}$ \\
landlocked & -0.018 & -0.060 & -0.037 & -0.035 \\
& $(6.38)^{* * *}$ & $(7.27)^{* * *}$ & $(4.81)^{* * *}$ & $(3.97)^{* * *}$ \\
agoaUS & 0.040 & & & \\
& $(5.49)^{* * *}$ & & & \\
ebaEU & 0.020 & & & \\
& $(6.20)^{* * *}$ & & & \\
comesa & & 0.004 & 0.060 & 0.075 \\
& & $(0.39)$ & $(4.57)^{* * *}$ & $(5.23)^{* * *}$ \\
ecowas & & 0.018 & 0.016 & 0.022 \\
& & $(2.67)^{* * *}$ & $(2.54)^{* *}$ & $(3.10)^{* * *}$ \\
euromedEU & 0.013 & & & \\
Constant & $(3.83)^{* * *}$ & & & \\
& 0.021 & -0.289 & 0.190 & 0.216 \\
Observations & $(1.58)$ & $(10.01)^{* * *}$ & $(4.18)^{* * *}$ & $(4.34)^{* * *}$ \\
& 1332157 & 529828 & 515568 & 471445
\end{tabular}

${ }^{\text {a }}$ USA, France, Germany and Italy

* significant at $10 \%$;* significant at $5 \% ; * * *$ significant at $1 \%$

Robust $\mathrm{z}$ statistics in parentheses

\section{Conclusions}

Africa has been lagging behind in terms of its manufacturing sector international competitiveness. Historically, the high dependence on primary commodities exports has constrained any process of export diversification (Lall, 2005). In addition, internal and external policy measures have negatively influenced the opportunity to increase external trade (Broadman, 2007). The model 
presented in this paper exploits the high disaggregation of trade data and allows us to draw some interesting evidence on the crowding out effect of China on African manufacturing exports:

- In general, standard trade-related variables have performed according to expectations: an increase in the rate of growth of the GDP of both exporters and importers has contributed to an increase in exports compared to the previous period; 'structural barriers to trade', i.e. the distance to market and the lack of an access to the sea, have refrained African countries from increasing their exports, with the latter being stronger compared to the former; free trade agreements have generally contributed to an improve of exports for those African countries that were officially involved in, with the noticeable exception of the ECOWAS, whose efficiency has been confirmed only for intra-African trade.

- Chinese exports have a negative sign both for the whole set of products exported and especially for the manufacturing sector. Thus, in general, whereas China and Africa compete, an annual increase in China's exports has corresponded to a decrease in African exports.

- Sectorally, there is evidence of displacement for a relevant number of industries. This is especially true for the cases of textiles and clothing (even more in footwear) and machinery and equipment (especially in typical medium technology productions of vehicles parts and components and the construction of machineries related to traditional sector of specialization). In addition, also other industries such as manufactures of chemicals and non metallic mineral products have suffered from Chinese competition.

- Geographically, a displacement effect has emerged when the sample of importers has been disaggregated by main developed markets. A very relevant result is the existence of a net displacement effect when the SSA market is taken into account. Results show that rising exports from China to SSA have come at the expense of intra-regional trade, with specific regard to intra-SSA trade.

\section{$\underline{\text { References }}$}

Amiti, M. and Freund, C. (2008), An Anatomy of China's Export Growth, paper prepared for the NBER project on the Evolving Role of China in the World Trade

Baltagi, B. (2005) Econometric Analysis of Panel Data, Third Edition- John Wiley and Sons Ltd The Atrium, Southern Gate, Chichester, England

Barnes, J. and Morris, M. (2008) Staying Alive in the Global Automotive Industry: what can Developing Economies learn from South Africa about Linking into Global Value Chains?, The European Journal of Development, 20 (1): 31-55

Baum, C.F., Schaffer, M.E. and Stillman, S. (2003) Instrumental Variables and GMM: Estimation and Testing, Boston College Economics Working Paper N. 545

Baum, C.F., Schaffer, M.E. and Stillman, S. (2007a) Enhanced Routines for Instrumental Variables/GMM Estimation and Testing, Boston College Economics Working Paper N. 667

Baum, C.F., Schaffer, M.E. and Stillman, S (2007b) ivreg2: Stata module for extended instrumental variables/2SLS, GMM and AC/HAC, LIML and k-class regression http://ideas.repec.org/c/boc/bocode/s425401.html

Bezuidenhout, H. and Naudé, W. (2008) Foreign Direct Investment and Trade in the Southern African Development Community, UNU-Wider Research Paper N. 2008/88

Biggeri, M. and Sanfilippo, M. (2009) Understanding China's Move into Africa: An Empirical Analysis, Journal of Chinese Business and Economic Studies, 7(1): 31-53

Broadman, H.G. (2007) Africa's Silk Road- China and India's new economic frontier, World Bank

Bun, M. and Klaassen, F. (2002) The Importance of Dynamics in Panel Gravity Models of Trade, Available at SSRN: http://ssrn.com/abstract=306100 or DOI: 10.2139/ssrn.306100 Cambridge, Massachusetts

Carey, K., Gupta, S. and Jacoby, U. (2007) Sub-Saharan Africa: Forging New Trade Links with Asia, Washington DC: International Monetary Fund 
Collier, P. and Venables, A. J. (2007) Rethinking Trade Preferences: How Can Africa Diversify its Exports, The World Economy: 1326-1345

Egger, P. and Pfarffermayr, M. (2005) Trade, Multinational Sales, and FDI in a Three-factor Model, Review of International Economics, 13(4): 659-675

Eichengreen, B., Yeongseop, R. and Tong, H. (2004) The Impact of China on the Exports of other Asian Countries, NBER Working Paper Series N. 10768

Eichengreen, B. and Tong, H. (2006) How China is Reorganizing the World Economy, Asian Economic Policy Review, 1: 73-97

Eifert, B., Gelb, A. and Ramachandran, V. (2005) Business Environment and Comparative Advantage in Africa: Evidence from the Investment Climate Data, Centre for Global Development Working Paper N. 56

Finger, K. M. (2008) Evolving wave of competition in the international market: Challenges forAfrica through the rise of China and India, preliminary draft version

Fontagné, L. and Zignano, S. (2007) A Re-Evaluation of the Impact of Regional Agreements on Trade Patterns, Integration and Trade, 26 January-June 2007

Fontagné, L., Gaulier, G. and Zignago, S. (2008), North-South Competition in Quality, Economic Policy January 2008: 51-91

Frazer, G. and Van Biesebroeck (2007) Trade Growth Under the African Growth and Opportunity Act, NBER Working Paper N. 13222

Gaulier, G., Zignano, S., Djeudonné, D., Sissoko, A.A. and Paillacar, R. (2008) BACI: A World Database of International Trade at the Product-level - the 1995-2004 Version, CEPII Working Papers N. 2007

Geda, A. and Kebret, H. (2007) Regional Economic Integration in Africa: A Review of Problems and Prospects with a Case Study of COMESA, Journal of African Economies, 17 (3): 357-394

Geda, A. and Meskel, A. G. (2007), China and India Growth Surge: Is it a Curse of Blessing for Africa? The Case of Manufacturing Exports, Open University Asian Drivers Programme resources list

Goldstein, A., Pinaud, N., Reisen, H. and Chen, X. (2006) The rise of China and India- What's in it for Africa?, Development Center Studies- OECD: Paris

Greenaway, D., Mahabir, A. and Milner, C. (2006), Has China Displaced Other Asian Countries Exports?, University of Nottingham Research Paper Series- China and the World Economy, N. 2006/21

Greene, W.H. 1993. Econometric Analysis $2^{\text {nd }}$ edition. New York: Macmillian.

IMF (2008) World Economic Outlook- April edition, International Monetary Fund

Institute of Development Studies (IDS) (2005), The Impact of Asian Drivers on the Developing World, Research Outline IDS

Jenkins, R. (2008), Measuring the Competitive Threat from China, UNU-Wider Research Paper N. 2008/11

Jenkins, R., and Edwards, C. (2004), How Does China's Growth Affect Poverty Reduction in Asia and Latin America?, Department for International Development (DFID)- United Kingdom

Jenkins, R., and Edwards, C. (2005) The Effect of China and India's Growth and Trade Liberalisation on Poverty in Africa, Department for International Development (DFID)- United Kingdom

Kaplinsky, R. (2005) Revisiting the revisited terms of trade: will China make a difference?, Working paper, Institute of Development Studies, Sussex

Kaplinsky, R. (2008) China and the Terms of Trade: the Challenge to Development Strategy in SSA, paper prepared for the Conference on "Rise of China: Global Opportunities and Challenges", Mount Holyoke, March 2008

Kaplinsky, R., and Messner, D. (2008), Introduction: the Impact of Asian Drivers on the Developing World, World Development 36, 2:197-209

Kaplinsky, R., and Morris, M., (2008), Do the Asian Drivers Undermine Export-oriented Industrialization in SSA?, World Development 36, 2:254-273

Kaplinsky, R. and Santos-Paulino, A. (2006) A disaggregated analysis of EU imports: the implications for the study of patterns of trade and technology, Cambridge Journal of Economics, 30: 587-611

Kaplinsky, R., McCormick, D. and M. Morris (2006) The Impact of China on Sub Saharan Africa, Institute of Development Studies, University of Sussex

Kleibergen, F. and Schaffer, M.E (2007), Ranktest: Stata module for testing the rank of a matrix using the Kleibergen-Paap rk statistic. http://ideas.repec.org/c/boc/bocode/s456865.html

Lall, S. (2005) Is African Industry Competing?, QEH Working Paper Series N. 121

Lall, S. and Albaladejo, M. (2004), China's Competitive Performance: A Threat to East Asian Manufactured Exports? World Development 32, 9: 1441-1466 
Morris, M. (2006) Globalization, China and Industrialization Strategies in Sub-Saharan Africa, in Jauch, H. and Traub-Merz, R (eds.), The Future of the Textile and Clothing Industry in Sub-Saharan Africa, Firedrich-Ebert-Stiftung, Bonn

Naughton, B. (2007) The Chinese Economy: Transition and Growth, the MIT Press

Palley, T.I. (2003) Export-Led Growth: Evidence of Developing Country Crowding-out, in Arestis, Baddeley, and McCombie (eds.), Economic Integration, Regionalism, and Globalization, Cheltenham: Edward Elgar

Qureshi, M.S. and Wan, G. (2008), Trade Expansion of China and India- Threat or Opportunity, UNU-Wider Research Paper N. 2008/08

Razmi, A. (2007), Pursuing Manufacturing-based Export-led Growth: are Developing Countries Increasingly Crowding Each Other Out? Working paper University of Massachusetts

Razmi, A. and Blecker, R. A. (2008) Developing Country Exports of Manufactures: Moving Up the Ladder to Escape the Fallacy of Composition?, Journal of Development Studies, 44 (1): 21 - 48

Rodrik, D. (2006), What is so Special About China's Exports?, Center for Economic Policy Research Discussion Paper N. 5484

Schott, P.K. (2008), Chinese Exports, Economic Policy, January 2008: 5-49

Shafaeddin, S.M. (2002) The Impact of China's Accession to WTO on the Exports of Developing Countries, UNCTAD Discussion paper N. 160/2002

Stevens, C. and Kennan, J., (2006) How to Identify the Trade Impact of China on Small Countries, IDS Bulletin, 27 (1): 33- 42

Subramanian, U. and Matthijs, M. (2007) Can Sub-Saharan Africa Leap into Global Network Trade? World Bank Policy Research Working Paper, N. 4112

Tegegne, G. E. (2006) Asian Imports and Coping Strategies of Medium, Small and Micro firms: The case of Footwear Sector in Ethiopia. Contribution to Workshop "The rapid Industrialization of China and India: Domestic and International Consequences" EADI Working Group on Industrial Development in the Third World, March, 31 - April, 1

UNCTAD (2008) Economic Development in Africa 2008 - Export Performance Following Trade Liberalization: Some Patterns and Policy Perspectives, United Nations Conference on Trade and Development, Geneva

UNECA (2008) Assessing Regional Integration in Africa III - Towards monetary and financial integration in Africa, United Nations Economic Commission for Africa: Addis Ababa

Wooldridge, J.M. (2002) Econometric Analysis of Cross Section and Panel Data, The MIT Press

World Bank (2007) Vertical and Regional Integration to Promote African Textiles and Clothing Exports- A close knit family? Report N. 39994, July 2007

Zafar, A. (2007) The Growing Relationship between China ad Sub- Saharan Africa: Macroeconomic, Trade, Investment, and Aid Links, The World Bank Research Observer, 22 (1): 103- 130 